\title{
The Use of Common E-Learning Tools towards State (Degree) of Scientific Literacy in Greek Second Chance Schools (SCS), during the First Wave of the COVID-19 Pandemic
}

\author{
Vasiliki Trapali, George Albert Karikas, Efstathia Papageorgiou, Christina Fountzoula, \\ Maria Trapali, Petros Karkalousos
}

Department of Biomedical Sciences, University of West Attica, Athens, Greece

Email: vtrapali@uniwa.gr

How to cite this paper: Trapali, V., Karikas, G. A., Papageorgiou, E., Fountzoula, C., Trapali, M., \& Karkalousos, P. (2022). The Use of Common E-Learning Tools towards State (Degree) of Scientific Literacy in Greek Second Chance Schools (SCS), during the First Wave of the COVID-19 Pandemic. Creative Education, 13, 167-182. https://doi.org/10.4236/ce.2022.131012

Received: December 11, 2021

Accepted: January 21, 2022

Published: January 24, 2022

Copyright $\odot 2022$ by author(s) and Scientific Research Publishing Inc. This work is licensed under the Creative Commons Attribution International License (CC BY 4.0).

http://creativecommons.org/licenses/by/4.0/

\begin{abstract}
Introduction: Reforming measures imposed by the COVID-19 pandemic in the Greek educational System, during the academic year 2020-2021 led to the implementation of distance learning in Second Chance Schools, for the first time. Trainers and trainees of Second Chance Schools, faced certain difficulties, with the arrival of the first COVID-19 wave, in March, April, May 2020 in Greece, being almost unprepared to use distance learning courses contemporary technologies aiming at provision and attendance. Purpose: To investigate and analyze the process of provision of synchronous and asynchronous distance learning of the scientific literacy trainers of Greece's Second Chance Schools, as well as, the trainers' opinion based on their individual-professional characteristics. Method: The use of a properly structured questionnaire, which was distributed among the scientific literacy trainers of the Second Chance Schools of Greece, was followed. The questionnaire was divided in three different groups. The interrelation between the variables (factor analysis) was investigated, while the most important data were re-investigated using the $\mathrm{x}^{2}$ (chi-squared). Results: $58.1 \%$ of the trainers used webex platform for the synchronous distance learning, with the $56.5 \%$ having educational experience in Second Chance Schools ranging 0 to 6 years $(p<0.01) .48 .4 \%$ used the "share screen" tool ( $p<0.01), 46.8 \%$ used the "raise hand" tool ( $p<$ $0.01)$ and $22.6 \%$ "presenter rights provision to the trainees" $(p<0.01) .64 .5 \%$ provided asynchronous distance learning via e-mail and $45.2 \%$ provided asynchronous distance learning with "delivery and acceptance of material to the Second Chance Schools", 32.3\% of which works in urban region Second Chance Schools $(p<0.01) .36 \%$ agreed with the statement that "scientific li-
\end{abstract}


teracy cannot be taught properly in distance learning", with the $27.9 \%$ attributing it in the "interrupted partake of the trainees" $(p<0.01)$ and $21.3 \%$ in the fact that "trainees are not fully accustomed to the technology" $(p<0.01)$. $43.5 \%$ disagreed with the statement that "distance learning covers sufficiently the curriculum which would be taught in person", with the $21.0 \%$ not having Informatics and Communication Technology (ICT) certificate $(p<0.05)$. Conclusion: The vast majority of the scientific literacy trainers that took part in the synchronous distance learning, in Second Chance Schools, are not pleased by the distance learning of scientific literacy in comparison with the adequacy and apprehension of the curriculum that would be taught in person.

\section{Keywords}

Distance Learning, E-Learning, Synchronus/Asynchronus Education, COVID-19, Platforms, Second Chance Schools (SCS), Scientific Literacy

\section{Introduction}

According to an UNESCO report (UNESCO, 2020), Greece was one of the 18 countries worldwide, that initiated the e-learning education, in March 2020, aiming at reducing COVID-19 spreading. The formal education was then changed and at the same time, informal Second Chance schools (SCS) for adults came to a really difficult situation.

SCS, operate in accordance with the philosophy of Adult Education based on the typical Secondary Education (Zepke \& Leach, 2006) adults at 18 or older, are given the opportunity to acquire a corresponding Junior High School diploma (Paper of Government, 1997). The duration of their studies is 18 months and the teaching hours are up to 25 per week.

Since 2000, 76 SCS institutions have been founded, in Greece. 12 of them are within detention centers 23 departments are outside of the local area, in the 13 regions of the country. SCS are operating, according to ELSTAT (2001), and characterized as urban, (>10,000 civilians), semi-urban, (ranging from 2000 to 10,000 civilians) and island/mountainous which excluding their geographical characteristics, exhibit the lowest population density and the highest housing density.

The schedules of the Greek SCS are not cohesive, but, they are flexible enough corresponding to the incohesive characteristics of the addressed adults (Institute for Constant Education of Adults, 2003). They are based on the principle of multiliteracy, namely the fact that a contemporary adult must possess "literacy" in various different scientific objects, apart from writing, reading and basic maths (Institute for Constant Education of Adults, 2003). Consequently, 8 literacies are formed: Linguistic, Arithmetic, Informatic, English, Social, Environmental, Scientific and Aesthetic-Cultural education. According to Prokou, the 
SCS study schedules aim against social exclusion, at the improvement of one's occupation and the active partaking of the civilians in the social, economic, political and cultural becoming (Prokou, 2009: p. 87). Specifically, the teaching of scientific literacy, strives for the appropriation of the trainees with forms of scientific knowledge that can be seen in variant situations of their everyday life (Hurd, 1998). Scientific literacy "stands for what the general public ought to know about science" (Durant, 1993: p. 129), and "commonly implies an appreciation of the nature, aims, and general limitations of science, coupled with some understanding of the more important scientific ideas" (Jenkins, 1994: p. 5345).

Since the outbreak of the COVID-19 pandemic in Greece, in March 2020, the SCS closing was announced, without Ministry of Education specific instructions, regarding the SCS management, in contrast with the rest formal Secondary Education. Thus, since 11/3/2020 until 30/6/2020 no official distance learning teaching hour had taken place in SCS all over the country. Simultaneously, SCS had no free of charge access to webex platform (distance school learning platform), as happened in the rest teaching units of the Greek territory.

The distance learning is implemented mandatorily for the first time in SCS, without however a clear framework from the Ministry of Education and Religious Affairs. Thus, every SCS, used, under mutual agreement between trainers and trainees, platforms vastly known, in which trainees of SCS could easily have access from their smart phone. The second phase of the pandemic led for the SCS to take a huge leap in the digital era.

In various articles regarding the actual views of the trainers of typical Education for the distance learning in Greece, while SCS trainers' articles are missing, even though the SCS trainers constitute a considerable percentage of the total number of trainers. Consequently, the written documentation of the SCS trainers concerning the implementation of distance learning, the academic year of 2020-2021, would gain indisputable interest.

\section{Purposes and Methods}

\subsection{Purpose of Project}

Main purpose of this project is to investigate the views of the scientific literacy trainers of the Greek SCS regarding distance learning during the academic year 2020-2021, which was implemented for the first time, in relation to their demographic-professional characteristics, with the main goal to suggest improving measures for an analogous feature situation.

More specific, apart from the set of questions regarding demographic and professional characteristics of the trainers, there have been also a number of questions categorized in two groups:

1) Which technical tools were used in present distance learning, the academic year 2020-2021?

2) What is your opinion regarding the implementation of the distance learning of Scientific Literacy? 


\subsection{The Study Sample}

SCS were chosen from different Greek regions categorized in urban, semi-urban and island/mountainous units, thus seeking possible existence of social parameters that could in some way characterized the trainers responds. 62 Scientific Literacy trainers, out of 103 took part in this synchronous distance learning the academic year of 2020-2021. The project took place in June 2021 (Table 1).

\subsection{Method, Questionnaire Structure, Research Material}

A quantitative research (Creswell, 2015) with appropriately modulated and structured questionnaire (google forms) (Isari and Pourkos, 2015), has been asked via e-mail to SCS that filled by the scientific literacy trainers in distance learning the academic year 2020-2021. In the questionnaire the five degree scale Likert has been adopted ( 1 "completely agree" to 5 "completely disagree"). The time to respond the questionnaire was about 10 minutes. The questionnaires consisted of three parts (Table 2) (Tables 3-5, Chart 1).

\subsection{Validity Check-Credibility Check}

The questionnaires, in pilot phase, were distributed among 8 scientific literacy Trainers of Western Greece's SCS in person, when they opened. The necessary clarifications were made and the questionnaires were filled with the presence of an investigator. The number of trainers was considered to be satisfactory for the objective and without biases deposition of their opinions (Cohen et al., 2008). The credibility factor (Cronbach's alpha) was considered so that it could be checked whether the questions show high cohesion between them. Regarding the first researching question the value of alpha was found to be $a=0.76$, for the

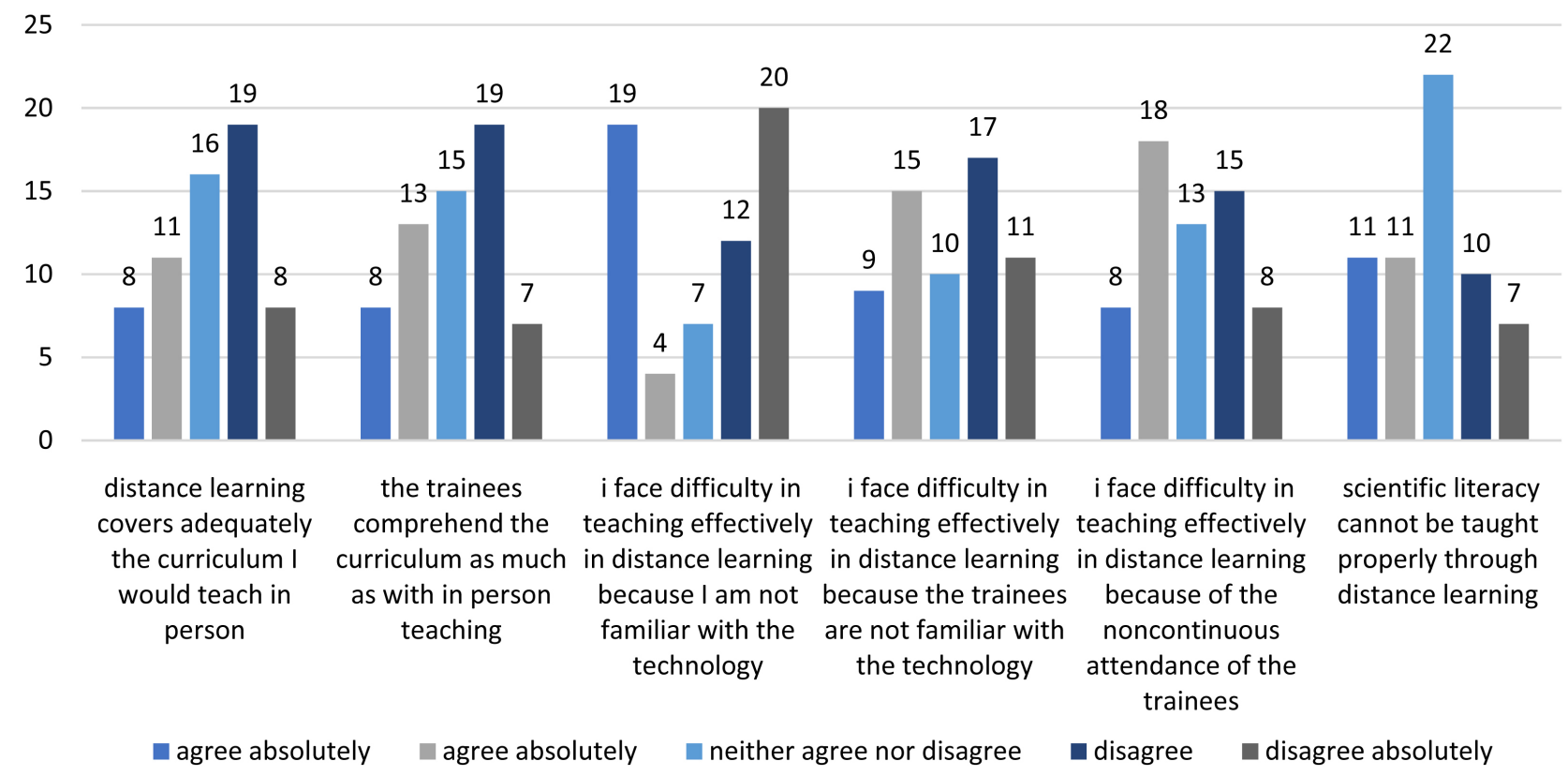

Chart 1 . The opinion of trainers regarding the implementation of scientific literacy distance learning. 
Table 1. The demographic and the professional data of the trainers were: In summary, $59.7 \%$ were women, $43.5 \%$ in the age group of $36-45,43.6 \%$ teaches Scientific Literacy with B degree assignment, while $21 \%$ of those with A degree assignment were chemists, the $69.4 \%$ holds a postgraduate-doctorate degree. $67 \%$ with a teaching experience in SCS for 0 - 3 years, while $50 \%$ with total teaching experience in Education for over 10 years. $51.6 \%$ is working in SCS of urban regions and $66.1 \%$ holds Informatics and Communication Technology degrees.

\begin{tabular}{|c|c|c|}
\hline Gender & \# of participants & Percentage \\
\hline Male & 25 & $40.3 \%$ \\
\hline Female & 37 & $59.7 \%$ \\
\hline Age group & \# of participants & Percentage \\
\hline Up to 35 & 12 & $19.4 \%$ \\
\hline $36-45$ & 27 & $43.5 \%$ \\
\hline $46-55$ & 18 & $29 \%$ \\
\hline 56 and older & 5 & $8.1 \%$ \\
\hline Specialty & \# of participants & Percentage \\
\hline Physicist & 19 & $30.6 \%$ \\
\hline Chemist & 13 & $21.0 \%$ \\
\hline Biologist & 2 & $3.2 \%$ \\
\hline Geologist & 1 & $1.6 \%$ \\
\hline \multirow[t]{2}{*}{ Other (specialty of B' assignment) ${ }^{1}$} & 27 & $43.6 \%$ \\
\hline & \# of participants & Percentage \\
\hline Tertiary education (degree) & 19 & $30.6 \%$ \\
\hline Postgraduate & 38 & $61.3 \%$ \\
\hline Doctorate & 5 & $8.1 \%$ \\
\hline Teaching experience in SCS & \# of participants & Percentage \\
\hline 0 - 3 years & 42 & $67 \%$ \\
\hline $4-6$ years & 12 & $19.4 \%$ \\
\hline 7 - 9 years & 3 & $4.8 \%$ \\
\hline 10 years and more & 5 & $8.1 \%$ \\
\hline \multicolumn{3}{|l|}{ Teaching experience in Education } \\
\hline $0-3$ years & 14 & $22.6 \%$ \\
\hline $4-6$ years & 9 & $14.5 \%$ \\
\hline 7 - 9 years & 8 & $12.9 \%$ \\
\hline 10 years and more & 31 & $50 \%$ \\
\hline \multicolumn{3}{|l|}{ Region of working in SCS } \\
\hline Urban & 32 & $51.6 \%$ \\
\hline
\end{tabular}


Continued

\begin{tabular}{ccc}
\hline Semi-urban & 22 & $35.5 \%$ \\
Island/Mountainous & 8 & $12.9 \%$ \\
Labor contract & & \\
Appointed & 12 & $19.4 \%$ \\
Substitute & 13 & $21.0 \%$ \\
Hourly wage & 36 & $58.1 \%$ \\
Voluntary & 1 & $1.6 \%$ \\
Informatics and & & \\
Communication Technology degree & & $66.1 \%$ \\
No & 41 & $33.9 \%$ \\
\hline
\end{tabular}

${ }^{1}$ Trainers of another specialty that teach physics in order to fill their mandatory schedule.

Table 2. Questionnaire groups and the number of questions/group.

\begin{tabular}{ccc}
\hline Groups & Type of questions & \# of questions \\
\hline First & Demographic-Professional data & 10 \\
Second & $\begin{array}{c}\text { Technical tools of scientific literacy distance learning } \\
\text { Third }\end{array}$ & $\begin{array}{c}\text { Opinion of trainers about the implementation of } \\
\text { distance learning during the academic year 2020-2021 }\end{array}$ \\
\hline
\end{tabular}

Table 3. The number of platforms used in synchronous distance learning. More than half of the trainers used the Webex platform.

\begin{tabular}{ccc}
\hline learning platforms & N & $\%$ \\
\hline Webex & 36 & 58.1 \\
Zoom & 15 & 24.2 \\
Viber & 11 & 17.7 \\
Messenger & 16 & 25.8 \\
Skype & 10 & 16.1 \\
Big Blue Button & 17 & 27.4 \\
\hline
\end{tabular}

Table 4. The tools of synchronous education platforms. The majority of the trainers used extensively the screen sharing and chat.

\begin{tabular}{ccc}
\hline Synchronous distance learning tools & N & $\%$ \\
\hline Chat & 44 & 71.0 \\
Share screen & 42 & 67.7 \\
Polls & 7 & 11.3 \\
Group splitting & 10 & 16.1 \\
\hline
\end{tabular}




\begin{tabular}{ccc}
\hline Hand raising & 29 & 46.8 \\
Co-teaching/co-presentation & 7 & 11.3 \\
Co-host rights for the Trainees & 14 & 22.6 \\
\hline
\end{tabular}

Table 5. The platforms or/and the tools of asynchronous distance learning. The majority of the trainers used the plain message sending via e-mail.

\begin{tabular}{ccc}
\hline Platforms/tools of asynchronous distance learning & N & $\%$ \\
\hline e-class ${ }^{2}$ & 19 & 30.6 \\
e-mail & 40 & 64.5 \\
Viber & 19 & 30.6 \\
Messenger & 27 & 43.5 \\
Delivery and acceptance of material from school & 28 & 45.2 \\
Other & 10 & 16.4 \\
\hline
\end{tabular}

${ }^{2}$ e-class is an educational platform of asynchronous education developed by the Greek Ministry of Education.

second $a=0.75$, and for the third researching question $a=0.815$. The variables/questions with $a<0.3$ were subtracted for the inner cohesion of the researching questions to be increased.

\section{Data statistical analysis}

The data were analyzed with SPSS 27.0 (academic license). Initially a descriptive statistical analysis for the depiction of the frequencies of all variables of the questionnaire was carried out. Moreover, a factor analysis was conducted and cohesion was sought with the purpose of emergence of dependence between the variables and the 4 groups of the questionnaire and the statistical trial chi-square was implemented, so that the most import relations could be digging out.

\section{Ethics and Deontology}

The Ethics Committee within the University of West Attica, approved the present project, which was conformed to the warrant of declaration of Helsinki regarding the researches with human beings. It was clarified for the participants that the questionnaire is anonymous and the data will be used exclusively for the statistical processing.

\section{Results}

Prior to the researching question, the variables/questions were analyzed with the methodology of factor analysis. Thus, we sought upon the interaction of the variables/questions among them with regard to the co-variance, and we focused on those variables alone, that seemed to play a primary role in the answers the researching questions that were posed. 


\subsection{Platforms of Synchronous Distance Learning and Tools That the Scientific Literacy Trainers of SCS Used the Academic Year 2020-2021}

It was investigated to what degree the choice of the platform and the tools used in distance learning of scientific literacy are related to the individual-professional characteristics of the trainers (Chart 2 and Chart 3). The differences between the answers were statistically significant $(p<0.05)$. The highest diploma degree and the teaching background in SCS, seemed to affect the choice of platform. More than half of the trainers that possess a Postgraduate/Doctorate diploma did not use skype, but newer platforms of synchronous distance learning. Of the $58.1 \%$ of the trainers that used webex, almost all had teaching background in SCS from 0 to 6 years, namely are trainers with relatively little background in SCS.

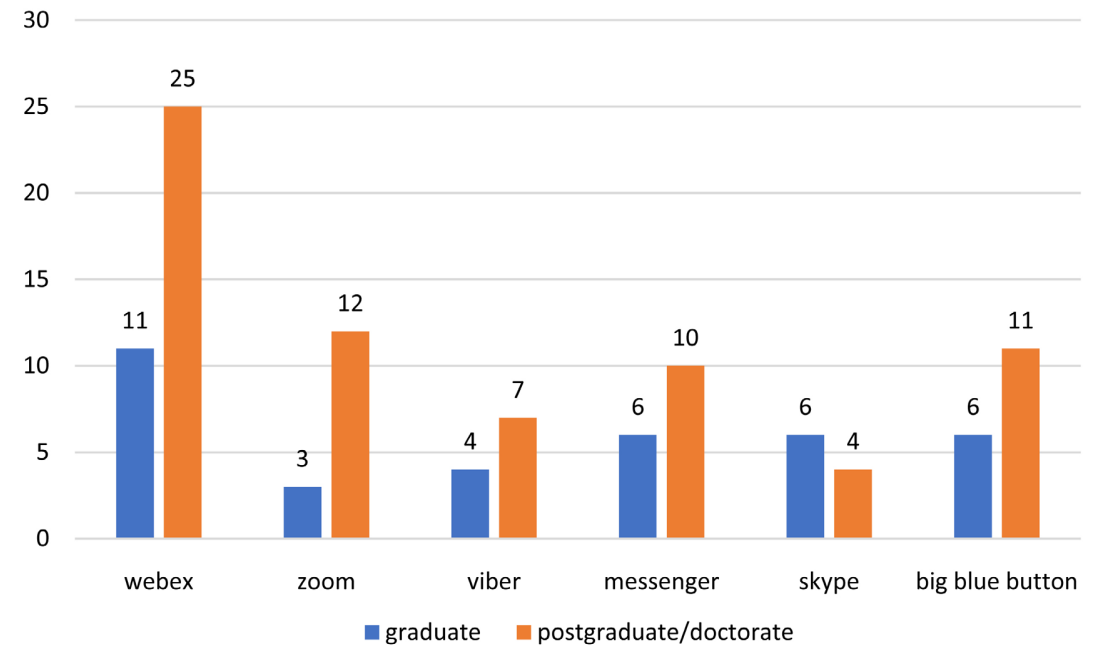

Chart 2. The view of the trainers regarding the way of provision of synchronous distance learning in relation to their highest diploma degree.

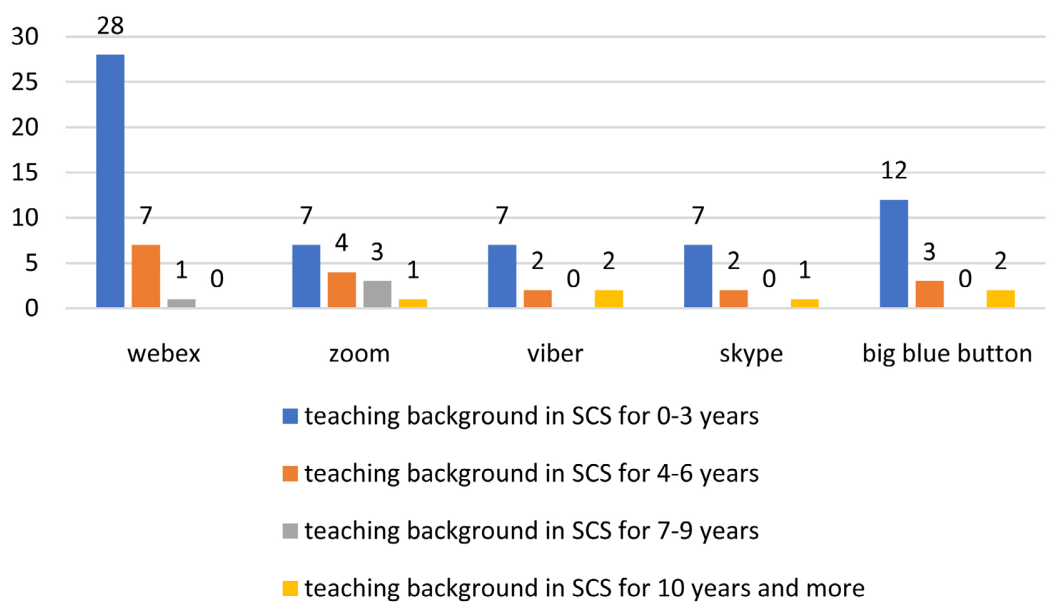

Chart 3. The kind of on-line platforms of distance learning that were used by the trainers in relation to their teaching experience. Almost all the trainers that used the platform webex had little background in SCS. 
The platforms used by the trainers were investigated and simultaneously questioned about the tools of each platform they are more familiar with. The differences between the answers were statistically significant $(p<0.05)$ (Chart 4 ). Of the $58.1 \%$ of the trainers that used webex platform for synchronous distance learning, almost all used the tool "share screen", more than have used the tool "raise hand" while only a few used the tool "presenter rights provision". $24.2 \%$ of the trainers that used zoom, almost all used the tool "chat" and "share screen". The highest percentage of the trainers that used the tool "presenter rights provision" used the platform big blue button.

\subsection{Platforms and Tools of Asynchronous Distance Learning That Were Used by Scientific Literacy Trainers of SCS the Academic Year 2020-2021}

One way of asynchronous teaching which were adopted by trainers of SCS was to hand out educative material right to their trainees through the SCS. The need for this was that many trainees have not had access to the internet or they were not familiar enough in using educative applications. $45.23 \%$ of the trainers that provided asynchronous distance learning with delivery and acceptance of material by the SCS, the vast majority (32.3\%) works in an urban region. The differences were statistically significant $(p<0.05)$ (Chart 5$)$.

The choice of asynchronous distance learning platform by the scientific literacy trainers is significantly related $(p<0.05)$ to whether they possess a certificate in informatics (Chart 6). 66.1\% of the trainers who have a certificate in information and communication technology, only a few used the e-class platform for synchronous education and this definitely has not occurred due to their lack of technical expertise.

\subsection{Data Analysis Regarding the Question "View of Scientific Literacy Trainers on the Implementation of Distance Learning"}

The degree the trainees comprehend the curriculum was investigated, at least as

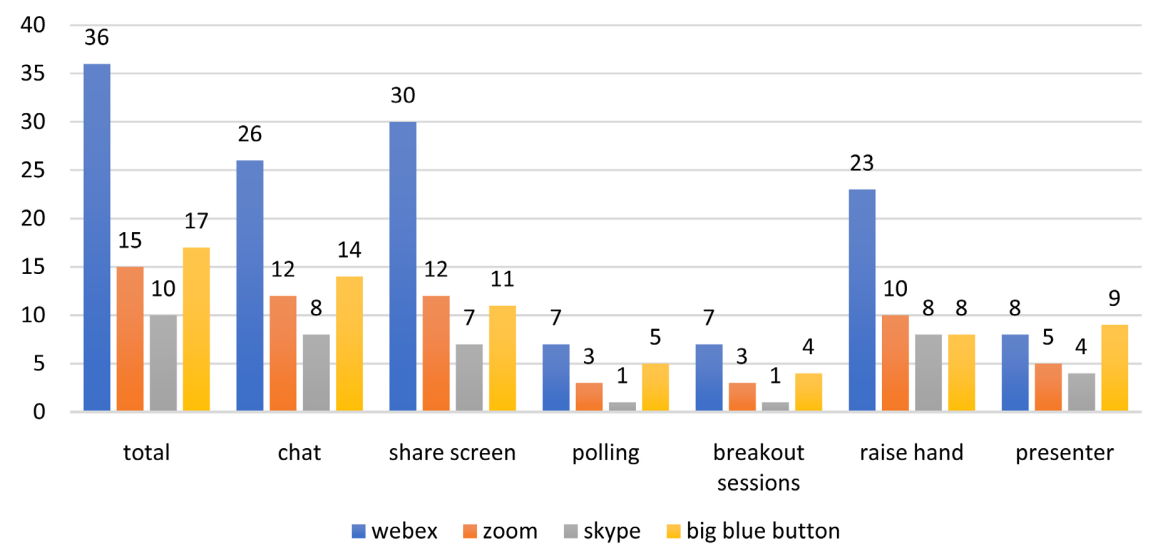

Chart 4. The use of synchronous distance learning tools from the scientific literacy trainers. The vast majority of the trainers used the tool share screen. 


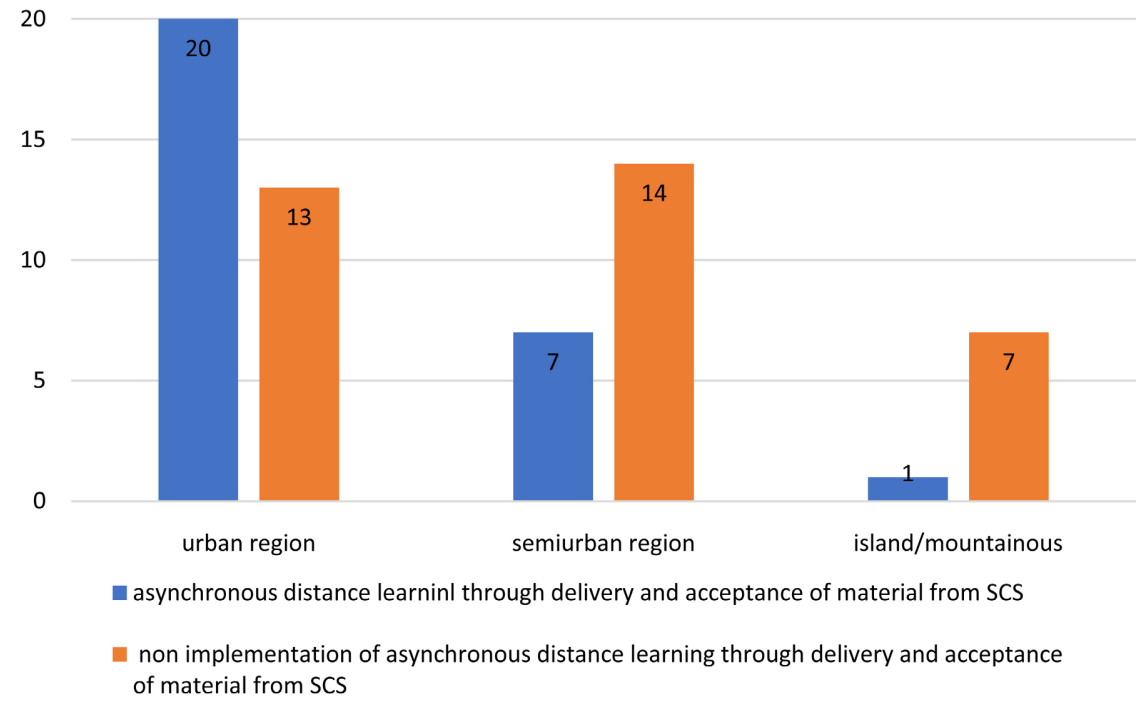

Chart 5. The process of asynchronous distance learning through delivery and acceptance of material from the SCS, which was featured by the trainers. In urban regions, distance learning comes to be the vast majority through this process.

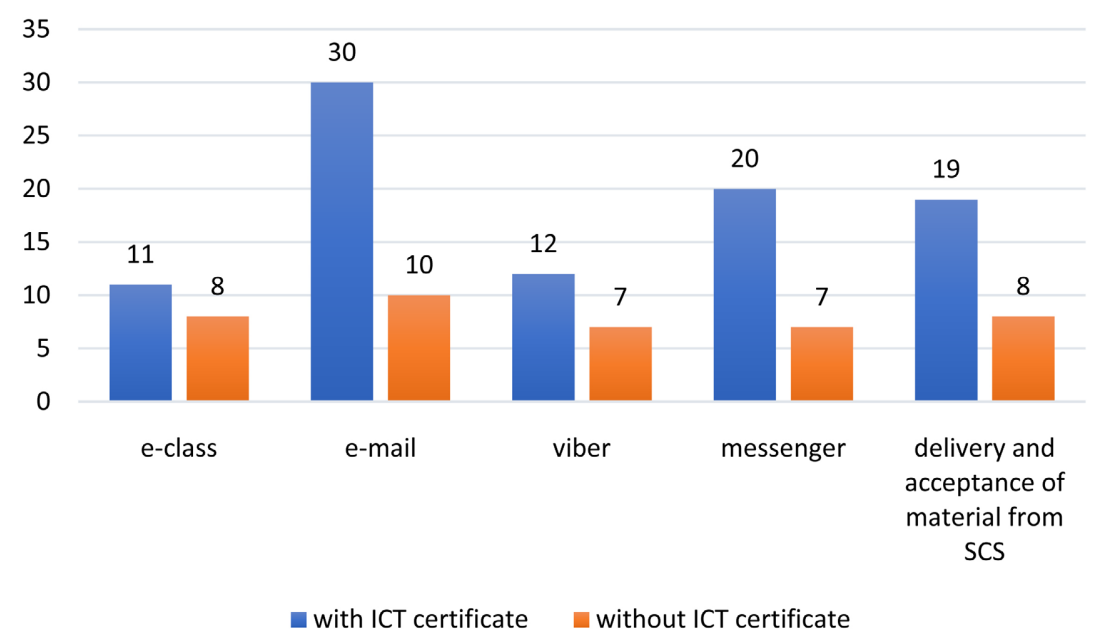

Chart 6. The tools of asynchronous distance learning used by the trainers. The vast majority of those with a certificate in informatics used e-mail for asynchronous distance learning.

much as in person education. Those responding were trainers who answered simultaneously the question to what degree they covered the curriculum of their class through the distance learning process (Table 6). The differences between the answers were statistically significant $(p<0.01)$. The majority of the trainers that covered fully the curriculum believe that trainees comprehended the curriculum as much as with in person education.

Concerning to what degree scientific literacy can be taught properly via distance learning, the questioned trainers answered simultaneously in questions 
Table 6. The investigation to what degree the trainees comprehended as much the curriculum as in person education when the classes are completed and the whole curriculum is covered. It seems that most trainers consider that the curriculum is not fully comprehended via distance learning.

\begin{tabular}{|c|c|c|c|c|c|}
\hline & & \multicolumn{4}{|c|}{$\begin{array}{l}\text { the trainees comprehend the curriculum } \\
\text { as much as with in person education }\end{array}$} \\
\hline & & $\begin{array}{l}\text { agree and } \\
\text { agree } \\
\text { absolutely }\end{array}$ & $\begin{array}{l}\text { neither } \\
\text { agree nor } \\
\text { disagree }\end{array}$ & $\begin{array}{c}\text { disagree and } \\
\text { disagree } \\
\text { absolutely }\end{array}$ & total \\
\hline \multirow{4}{*}{$\begin{array}{l}\text { the distance } \\
\text { learning classes } \\
\text { cover adequately } \\
\text { the curriculum } \\
\text { I would teach } \\
\text { in person }\end{array}$} & $\begin{array}{l}\text { agree and agree } \\
\text { absolutely }\end{array}$ & $21.0 \%$ & $8.1 \%$ & $1.5 \%$ & $30.6 \%$ \\
\hline & $\begin{array}{l}\text { neither agree } \\
\text { nor disagree }\end{array}$ & $9.7 \%$ & $6.5 \%$ & $9.7 \%$ & $25.9 \%$ \\
\hline & $\begin{array}{c}\text { disagree and } \\
\text { disagree absolutely }\end{array}$ & $3.2 \%$ & $9.7 \%$ & $30.6 \%$ & $43.5 \%$ \\
\hline & total & $33.9 \%$ & $24.3 \%$ & $41.8 \%$ & $100.0 \%$ \\
\hline
\end{tabular}

that traced possible hardships emerging during distance learning (Table 7 and Table 8). The differences between their answers were statistically significant $(p<$ 0.01 ). More than half of the trainers that believe that scientific literacy cannot be properly taught via distance learning, attribute it in the interrupted attendance of the trainees and in the non-familiarity of the trainees with the technology used. Almost all trainers believe that the inadequacy of scientific literacy distance learning occurs due to the interrupted attendance of the trainees and the lack of know-how on their part.

The emerging result from the views of those with a certificate in informatics regarding the adequacy of the curriculum via distance learning is particularly important (Chart 7). The scientific literacy trainers with a certificate in informatics seem to agree with the opinion that distance learning covers adequately the curriculum as much as with in person education (statistical significance $p<$ 0.05). This discovery shows that the familiarization of the trainers with the current technology reinforces their positive stance towards distance learning.

Simultaneously, present investigation uncovered whether the kind of used platform affected the view of the trainers on the adequacy of the curriculum through the hardships they encountered in distance learning (Chart 8 and Chart 9). The differences between the answers were statistically significant $(p<0.01)$. More than half of the trainers that used the platform zoom, were not bothered or troubled by the interrupted attendance of the trainees. The trainees seemed to pay attention without interruption problems through zoom platform, (possibly, they had installed the app in their smartphones and their connection through the link that their trainers sent them was easy). Furthermore, the majority of the trainers that used the platform of asynchronous distance learning e-class, developed by the Greek Ministry of Education, believe that the curriculum was taught adequately. 
Table 7. Investigation of to what degree the noncontinuous partake of the trainees in the educative process prevents the teaching through distance learning. $22.9 \%$ of the trainers consider that the inadequate education in distance learning can be attributed in the noncontinuous attendance of the trainees.

\begin{tabular}{|c|c|c|c|c|c|}
\hline & & \multicolumn{4}{|c|}{$\begin{array}{l}\text { I face difficulty teaching efficiently in distance } \\
\text { learning due to the noncontinuous } \\
\text { attendance of the trainees }\end{array}$} \\
\hline & & $\begin{array}{l}\text { agree and } \\
\text { agree } \\
\text { absolutely }\end{array}$ & $\begin{array}{l}\text { neither } \\
\text { agree nor } \\
\text { disagree }\end{array}$ & $\begin{array}{l}\text { disagree and } \\
\text { disagree } \\
\text { absolutely }\end{array}$ & total \\
\hline \multirow{4}{*}{$\begin{array}{l}\text { scientific literacy } \\
\text { cannot be taught } \\
\text { properly through } \\
\text { distance learning }\end{array}$} & $\begin{array}{l}\text { agree and agree } \\
\text { absolutely }\end{array}$ & $22.9 \%$ & $3.3 \%$ & $9.8 \%$ & $36.1 \%$ \\
\hline & $\begin{array}{l}\text { neither agree } \\
\text { nor disagree }\end{array}$ & $11.5 \%$ & $14.8 \%$ & $9.8 \%$ & $36.1 \%$ \\
\hline & $\begin{array}{c}\text { disagree and } \\
\text { disagree absolutely }\end{array}$ & $6.6 \%$ & $3.3 \%$ & $18.0 \%$ & $27.9 \%$ \\
\hline & total & $41.0 \%$ & $21.4 \%$ & $37.6 \%$ & $100.0 \%$ \\
\hline
\end{tabular}

Table 8. Investigation of to what degree the little appropriation of trainees with technology prevents the education through distance learning. The majority of the trainers attribute the inadequacy of distance learning to the fact that trainees are not familiar with current technology.

\begin{tabular}{|c|c|c|c|c|c|}
\hline & & \multicolumn{4}{|c|}{$\begin{array}{c}\text { I face difficulty teaching efficiently in distance } \\
\text { learning because the trainees are not familiar } \\
\text { with current technology }\end{array}$} \\
\hline & & $\begin{array}{l}\text { agree and } \\
\text { agree } \\
\text { absolutely }\end{array}$ & $\begin{array}{l}\text { neither } \\
\text { agree nor } \\
\text { disagree }\end{array}$ & $\begin{array}{l}\text { disagree and } \\
\text { disagree } \\
\text { absolutely }\end{array}$ & total \\
\hline \multirow{4}{*}{$\begin{array}{l}\text { scientific literacy } \\
\text { cannot be taught } \\
\text { properly through } \\
\text { distance learning }\end{array}$} & $\begin{array}{l}\text { agree and agree } \\
\text { absolutely }\end{array}$ & $21.3 \%$ & $6.6 \%$ & $8.2 \%$ & $36.1 \%$ \\
\hline & $\begin{array}{l}\text { neither agree } \\
\text { nor disagree }\end{array}$ & $11.5 \%$ & $6.6 \%$ & $18.0 \%$ & $36.1 \%$ \\
\hline & $\begin{array}{c}\text { disagree and } \\
\text { disagree absolutely }\end{array}$ & $6.6 \%$ & $1.6 \%$ & $19.7 \%$ & $27.9 \%$ \\
\hline & total & $39.3 \%$ & $14.8 \%$ & $45.9 \%$ & $100.0 \%$ \\
\hline
\end{tabular}

\section{Conclusion}

Platforms and tools of synchronous distance learning used by the scientific literacy trainers of the SCS the academic year 2020-2021

The highest diploma degree that the trainers possess and the teaching experience in SCS, are significantly related to the synchronous distance learning platform they chose to use during the academic year 2020-2021. The majority of the trainers that have not used the platform skype, possess a postgraduate/doctorate diploma as a highest diploma degree. It seems consequently that the trainers 


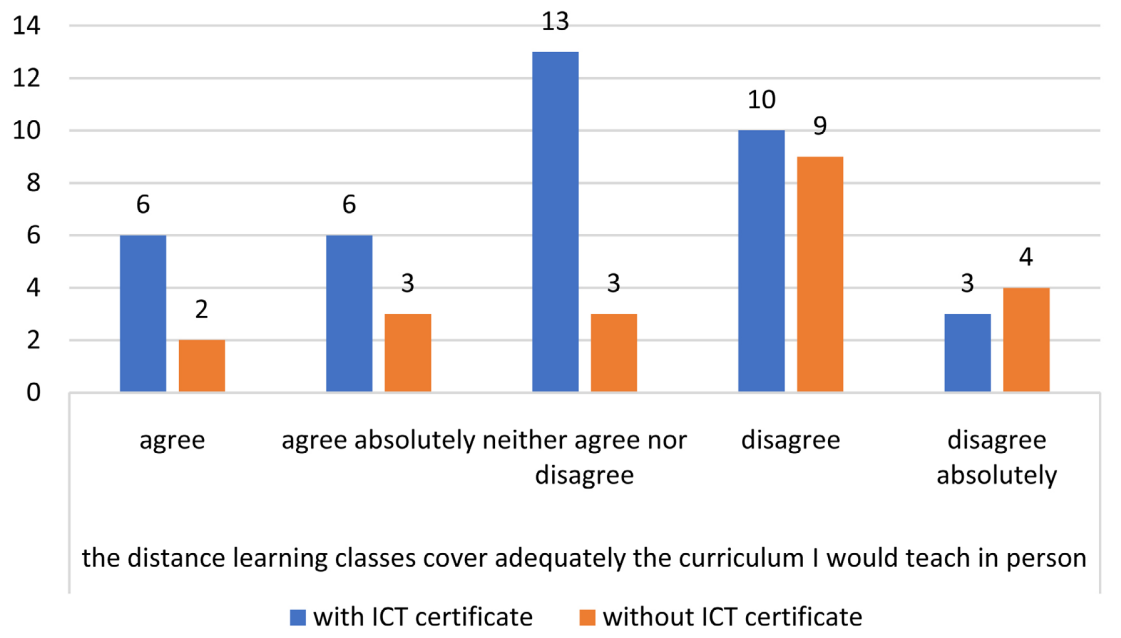

Chart 7. Trainers view regarding the coverage of the curriculum through distance learning. It seems that the trainers that covered the curriculum were those who had already an expertise or certificate in informatics.

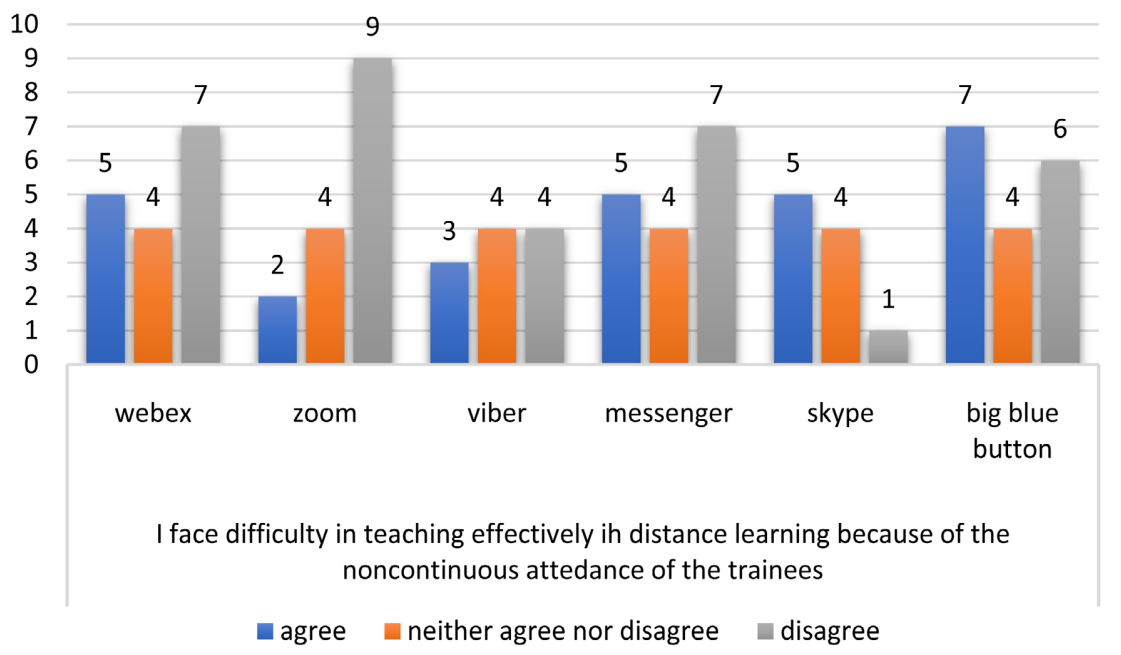

Chart 8. The view of the trainers regarding the hardship of efficient distance learning due to difficulties of interrupted connections of the trainees. The majority of the trainers that used the platform of synchronous education zoom, does not attribute the inadequacy of distance learning in the noncontinuous attendance of the trainees.

with higher educational qualifications, use more contemporary methods of distance learning in as much the platform skype will be soon abolished.

The platform webex was used by the majority of the trainers with a teaching background in SCS from 0 to 6 years. This means that the younger trainers used more frequently the platforms that the Greek Ministry of Education proposed.

The majority of the trainers that used webex platform for synchronous distance learning, used the "share screen" and "raise hand" tools, while did not use the "presenter rights provision". One can attribute this to the fact that the SCS trainees could not cope due to the lack of know-how regarding informatics, in the co-handistance learning in of the platform tools. 


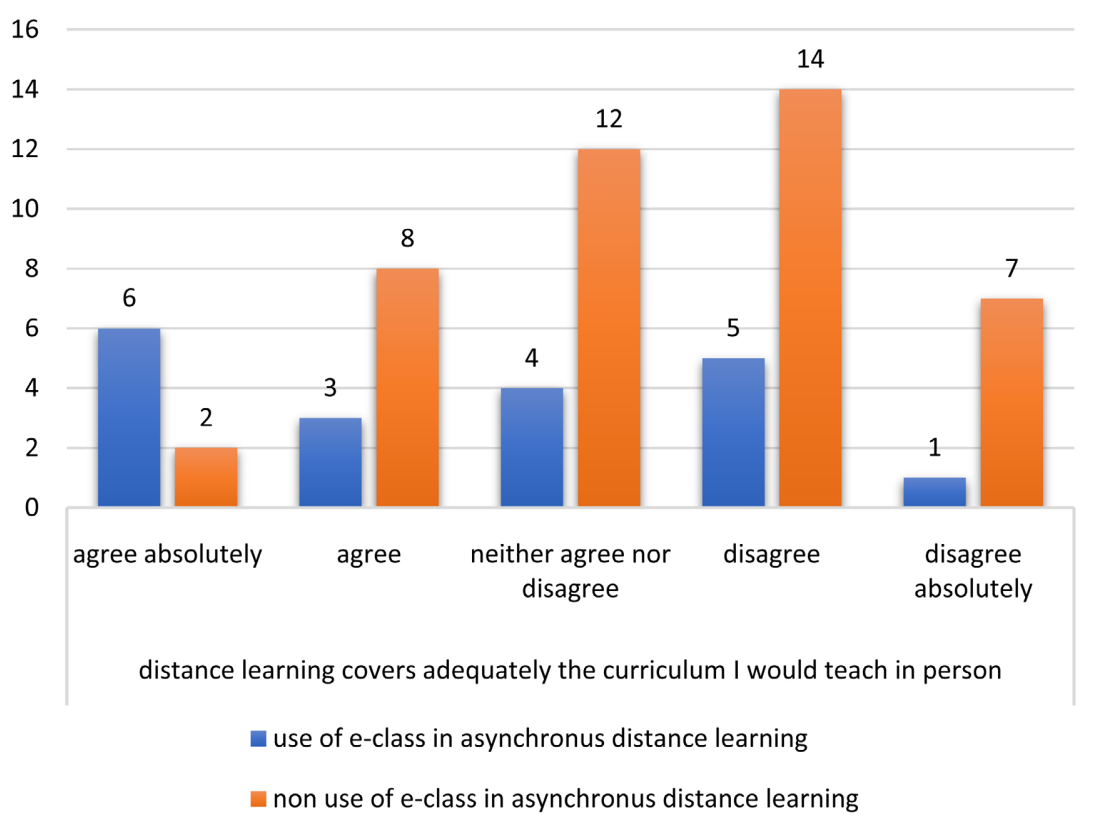

Chart 9. The view of the trainers regarding the coverage of the curriculum through exclusive use of the platform of asynchronous education instead of on-line education. The majority of the trainers that used exclusively asynchronous education consider that the expected curriculum was covered.

\section{Platforms and tools of asynchronous distance learning used by the scien- tific literacy trainers of the SCS the academic year 2020-2021}

The way of implementation of asynchronous distance learning in parallel with the synchronous, implemented by the trainers during the academic year 2020-2021, is significantly depended to the type of region that SCS is located. The majority of the trainers that chose to hand out educational material/projects to the trainees works in an urban SCS region, while only few trainers used the Greek Ministry of Education e-class platform. It seems that in urban regions the access to School was easier, even in a period of a pandemic, and that constituted a hybrid solution of asynchronous distance learning. On the other side, few trainers used the platform of the Ministry e-class, since possibly it was not easily accessible by the trainees.

View of scientific literacy trainers on the implementation of distance learning

The majority of the scientific literacy trainers believe that scientific literacy cannot be taught properly through distance learning and also, an equal percentage cannot pronounce on it. They mainly attribute it in two parameters: a. in the interrupted attendance of the trainees, due to connection problems and $b$. in the fact that the SCS trainees are not familiar with the advanced technology. They actually mentioned that distance learning classes did not cover adequately the curriculum that would be taught in person and they attribute this mainly to the fact that the trainees do not comprehend the curriculum as much as they would with in person education. It appears, from the trainers' side that distance 
learning as a singular way of teaching, cannot lead to a deeper penetration of the curriculum from the trainees' side.

\section{Discussion-Proposals}

The scientific literacy trainers of the SCS in Greece are, in majority, women, aged 36 - 45 years old, hourly waged, owners of a postgraduate diploma, that teach as B' assignment. The present assessment showed that the scientific literacy trainers consider they cannot teach adequately the curriculum through distance learning and they relate this view with the noncontinuous attendance of the trainees and with the fact that the trainees of the SCS are not familiar with the current technology.

Some practical proposals towards the resolution of these detected problems could be:

1) Financial support of the trainees to covering the cost the appropriate equipment and a stable and fast internet connection.

2) Financial support of the SCS, in order to gain cyber equipment, which could be lent to the trainees.

3) Targeted education offer to trainers regarding the use of the internet/e-mail and the use of synchronous and asynchronous distance learning. This educational program could be given in the beginning the academic year, with properly designed skill workshops, either as main education in the periods of the pandemic or as subsidiary of the in-person education.

4) Targeted education offer of the scientific literacy trainers concerning the design and implementation of educative seminars on distance learning.

To conclude, living in the age of vertiginous progress of technology and its embodiment in education a contemporary educative environment could be modulated where all the SCS could use a distance learning education platform, specifically adjusted to the characteristics of this type of, both in periods of mandatory interruption and as a medium of additional provision of education.

In any case, however, the assurance of equal access to the internet for all trainees and their elementary appropriation, where needed, remains a fundamental requirement.

The coming years the education through distance learning in SCS will be a first priority in Greece. Educative organizations and scholars must find a practically applicable framework as for the provision through distance in SCS, taking seriously into consideration the special characteristics of the trainees and the philosophy of Education based on the interconnection of its members.

\section{Conflicts of Interest}

The authors declare no conflicts of interest regarding the publication of this paper.

\section{References}

Cohen, L., Manion, L., \& Morrison, K. (2008). Research Methods in Education. Rout- 
ledge. https://doi.org/10.4324/9780203029053

Creswell, J. (2015). Research Design: Qualitative, Quantitative and Mixed Methods Approaches. Pearson Education Inc.

Durant, J. R. (1993). What Is Scientific Literacy? In J. R. Durant \& J. Gregory (Eds.), Science and Culture in Europe (pp. 129-137). Science Museum.

ELSTAT (2001). Geodata.gov.gr. https:/geodata.gov.gr/dataset/apographe-plethusmou-2001

Hurd, P. D. (1998). Scientific Literacy: New Minds for a Changing World. Journal of Science Education, 82, 407-416. https://doi.org/10.1002/(SICI)1098-237X(199806)82:3<407::AID-SCE6>3.0.CO;2-G

Institute for Constant Education of Adults (2003). Schooling Specifications for Second Chance Schools. Publication of Institute for Constant Education of Adults.

Isari, F., \& Pourkos, M. (2015). Qualitative Research Methodology. Greek Academic Books Association.

Jenkins, E. W. (1994). Scientific Literacy. In T. Husen \& T. N. Postlethwaite (Eds.), The International Encyclopedia of Education (Vol. 9, 2nd ed., pp. 5345-5350). Pergamon Press.

Paper of Government (1997). Law 2525/97: Undivided High School, Access for the Graduates in Tertiary Education, Evaluation of the Educative Work and Other Provisions. https://www.e-nomothesia.gr/kat-ekpaideuse/n-2525-1997.html

Prokou, E. (2009). Education of Adults and Lifelong Learning in Europe and Greece. Dionikos Publications.

UNESCO (2020). Distance Learning Strategies in Response to COVID-19 School Closures. UNESCO COVID-19 Education Response, Education Sector Issue Notes, No 2.1. https://unesdoc.unesco.org/ark:/48223/pf0000373305

Zepke, N., \& Leach, L. (2006). Improving Learner Outcomes in Lifelong Education: Formal Pedagogics in Non-Formal Learning Contexts? International Journal of Lifelong Education, 25, 507-518. https://doi.org/10.1080/02601370600912089 